This item was submitted to Loughborough's Research Repository by the author.

Items in Figshare are protected by copyright, with all rights reserved, unless otherwise indicated.

\title{
Against the wall: anarchist mobilization in the Israeli-Palestinian conflict
}

PLEASE CITE THE PUBLISHED VERSION

http://dx.doi.org/10.1111/j.1468-0130.2010.00641.x

\section{PUBLISHER}

Wiley $@$ Peace History Society and Peace and Justice Studies Association

\section{VERSION}

AM (Accepted Manuscript)

\section{PUBLISHER STATEMENT}

This work is made available according to the conditions of the Creative Commons Attribution-NonCommercialNoDerivatives 4.0 International (CC BY-NC-ND 4.0) licence. Full details of this licence are available at: https://creativecommons.org/licenses/by-nc-nd/4.0/

\section{LICENCE}

CC BY-NC-ND 4.0

\section{REPOSITORY RECORD}

Gordon, Uri. 2019. "Against the Wall: Anarchist Mobilization in the Israeli-palestinian Conflict”. figshare. https://hdl.handle.net/2134/15916. 
Against the Wall: Anarchist Mobilization in the Israeli-Palestinian Conflict

\section{by Uri Gordon}

Abstract: Anarchists Against the Wall is an Israeli action group supporting the popular Palestinian struggle against segregation and land confiscation in the West Bank. Incorporating participant observation and recent theories of social movements and anarchism, this article offers a thick cultural account of the group's mobilization dynamics, and assesses the achievements and limitations of the joint struggle. Three dimensionsdirect action, bi-nationalism, and leadership-highlight the significance of anarchist practices and discourses to an informed assessment of the group's politics of nonviolent resistance. The effectiveness of the campaign is then examined, calling attention to the distinction among immediate, medium term, and revolutionary goals.

On a cloudy morning in June 2005, contractors and soldiers arriving on the lands of Bil'in to construct another section of Israel's Separation Fence / Apartheid Wall were confronted by an unusual obstruction. Inside a massive cage erected overnight on the concourse of bulldozed earth were four Palestinian residents of the West Bank village (a man and three women), three Israelis, three internationals, and a goat. Banners on the barbed wires surrounding the cage proclaimed, "The darkness must end, the handcuffs must be broken." While the state forces eventually lifted the cage with heavy machinery and made arrests, the action both directly disrupted construction and symbolically highlighted the imprisonment of Palestinian communities behind the fence as well as Israeli and international solidarity with them. This article examines the role of Israeli anarchists active in the West Bank and offers a critical account of their activities and discourses as they struggle shoulder to shoulder with Palestinians against a regime of creeping land confiscation, military repression, and restricted freedom of movement. Its main argument is that the case of Israel / Palestine strongly demonstrates the contribution of anarchist practices and discourses to the dynamism and resilience of antiwar movements, particularly in environments of protracted conflict. In the following pages, I seek to elaborate the ways in which the anarchist logic of direct action and a priori detachment from nationalist narratives has contributed to an unprecedented bi-national resistance campaign in Israel/Palestine, which deserves serious attention from students of antiwar movements (a category that should include movements working to end protracted conflicts and military occupations, not just discrete wars).

Israeli anarchists are few in numbers. Though no hard data exist, on my own rough estimate there are up to three hundred Israelis who are politically active and who would not object to being called anarchists. Most of them are European-Jewish women and men ages 16-35 (with one vigorous septuagenarian). A majority of those under 30 have not served in the army. Despite small numbers, the initiative has succeeded in eroding Israeli enthusiasm for the fence, and has helped to create a unique laboratory of joint bi-national struggle in the midst of a trenchant, violent conflict. Anarchists' activities are reshaping the lexicon of war resistance with the language of direct action and partnership across supposedly unbreachable divides.

While the struggle against the occupation is (and should be) a Palestinian-led struggle, this article makes the explicit choice to focus on the Israelis acting in solidarity with them. This is not to detract from the fact that Palestinians, not Israelis, are the resisting oppressed in this story. But there are insights to be gained from a focus on the role of disobedient citizens of the occupying state itself in resistance to militarist policies and rhetoric that may be valuable 
for assessing the experiences of contemporary antiwar movements in the United States, Britain, and elsewhere.

The discussion draws on ongoing participant research in Israeli and international anarchist networks and reflects the prominence and legitimacy that anthropological methods such as participant observation, semi-structured interviews, and auto-ethnography are gaining in the study of popular movements.1 These methods are best suited to researching informal, semi-structured organizations, and movements, and in particular, to producing a highresolution analysis of decision making processes, power relations, organizational culture, symbolism, and the construction of social links. Participant observation was conducted in 2006-2007 during actions to remove roadblocks and defend olive harvesters, at joint demonstrations, and in protests inside Israel. Semi-structured interviews were conducted with a number of participants in the group and with further perspectives collected by attending group meetings and following its e-mail list.

Following a clarification on the substance of anarchist political culture, I proceed to review the emergence of contemporary Israeli anarchism and the joint struggle in the West Bank against the construction of the barrier variously known as the "Separation Fence" and the "Apartheid Wall." The central section analyzes the dimensions of direct action, binationalism, and leadership in the group's activity, stressing the role of anarchist politics in shaping the dynamics of the mobilization and its attendant dilemmas. The final section assesses the campaign's sustainability and effectiveness, highlighting the difficulties generated by regular exposure to state repression, and examining its success in achieving its goals. I conclude that the group's medium-term goals, eroding the legitimacy of segregation and sustaining a bi-national alliance, were the most successful element of the mobilization.

\section{THE NEW ANARCHISM IN ISRAEL}

The past ten years have seen the full-blown revival of a global anarchist movement, possessing a coherent core political practice, on a scale and scope of activity unseen since the 1930s. From anti-capitalist social centers and eco-feminist communities to raucous street parties and blockades of international summits, anarchist forms of resistance and organizing have effectively replaced Marxism as the chief point of reference for radical politics in advanced capitalist countries.2 Contemporary anarchism is "new" in that it is only in small part a direct continuation of the nineteenth- and early twentieth-century anarchist movements, which had been for the most part physically wiped out by the end of the Second World War. Instead, anarchism has been resurrected at the points of intersection between radical social movements whose beginnings were usually not overtly anarchist: militant ecology and feminism, anti-nuclear and antiwar movements, radical queer and punk subcultures, animal rights groups, and movements for black and indigenous liberation. Accelerating networking and cross-fertilization among the radical, direct-action ends of these movements led to a convergence of political cultures and ideas that reached critical mass around the turn of the millennium with the global wave of resistance to neoliberal capitalism.

The present discussion is thus informed by an understanding of anarchism primarily as a political culture shared across a decentralized global network of affinity groups and collectives. Some of this culture's major features are:

1. a repertoire of action combining direct action, community building, street confrontation, and countercultural production; 
2. anti-hierarchical forms of organizing based on voluntary association, consensus, and fluidity; and

3. a political language and discourse whose core ideas have unmistakable affinity with the revolutionary anarchist tradition.

The direct ethnographic encounter with this last element forms the basis for analyzing the central discursive markers delineating contemporary anarchism as an ideological family. 3 Three themes stand out: the rejection of hierarchical society and all regimes of social domination including capitalism, the state, patriarchy and racism; an ethos of direct action, which stresses unmediated intervention to confront injustices and challenge hierarchy, side by side with the self-organized creation of alternative social spaces; and an emphasis on diversity as a key value, resulting in open-ended goals and a tendency to reject utopian blueprints in favor of experimentation and creativity.

In Palestine/Israel, anarchism has been a continuous undercurrent for decades, from the libertarian socialism of the early kibbutz movement to the Yiddish anarchist publishing and cultural clubs of the 1950s.4 Contemporary Israeli anarchism first emerged in the punk scene of the late 1980s, at a time of parallel growth in army refusal and evasion during the first intifada. The Israeli animal liberation movement emerged from the same milieu, and many Israeli anarchists have been part of both movements. The major boost arrived in the late 1990s with the wave of resistance to capitalist globalization. Just as anti-roads protests were central to the consolidation of the British anarchist movement, 5 so was the grassroots struggle against the construction of the Cross-Israel Highway, which involved civil disobedience and acts of sabotage, a radicalizing experience for many young activists despite its ultimate failure to prevent the construction. The intersection of issues implicated in the campaign-pollution and open spaces, Arab land rights, and the collusion between government and corporate interests-led to the development of a strong environmental justice agenda in Israel.6 Further inspired by the major anti-capitalist protests in London and Seattle at the end of 1999, Israeli activists began organizing Reclaim the Streets parties and Food Not Bombs stalls, and founded the Salon Mazal infoshop and the Israeli Independent Media Center (Indymedia). This period also saw the spread of characteristically anarchist organizational methods: affinity groups, decision making by consensus, and networking through cultural events, periodic gatherings, and an extensive use of e-mail and Web sites.7

The eruption of the second, armed intifada in 2000 quickly drew the focus of Israeli radicals away from issues of environmental justice and globalization to the more immediate and acute issues of occupation and military violence on their doorstep. Initially, the major organ for Israeli solidarity with Palestinian communities was Ta'ayush (Arab-Jewish Partnership), a network that at its peak had hundreds of active participants, both Jews and Palestinian citizens of Israel. Though not nominally anarchist, Ta'ayush organized by consensus and without formal membership, and carried out direct, on-the-ground solidarity actions with Palestinian communities, e.g., bringing food to besieged cities and towns, and defending Palestinian farmers from settlers and soldiers as they cultivated their land.

From the summer of 2001, many international anarchists began arriving in the region as volunteers in the International Solidarity Movement (ISM), a Palestinian-led coordination that mobilized Europeans and North Americans to accompany nonviolent Palestinian actions in the West Bank. ISM actions included forming human chains to block soldiers from interfering while Palestinians tore down military roadblocks, held mass demonstrations, or collectively broke curfews to take children to school or tend their fields. ISM co-founder 
Ghassan Andoni estimates that about 20 percent of ISM volunteers have been Jewish. 8 In spring 2002, upon the intensification of Israeli violence in the West Bank, including the destruction of the Jenin refugee camp and the siege on the Church of the Nativity in Bethlehem, the ISM was driven to more defensive activities of human shielding and live witnessing. ISM activists stayed in Palestinian homes facing demolition, rode with ambulances, escorted municipal workers to fix infrastructures, and delivered food and medicine to besieged communities. As the violence ebbed the ISM turned proactive again, organizing more demonstrations to break curfews and an international day of solidarity with the Palestinians.9

The spring of 2003 saw a profound crisis in the ISM, following a rapid succession of tragic events. The killing of ISM volunteers Rachel Corrie and Tom Hurndall in the Gaza Strip served as an effective deterrent, severely reducing the flow of internationals into the region. Subsequently, the Israeli government launched a campaign against the ISM, falsely accusing it of harboring terrorists, and the army raided the ISM media office in Beit Sahour. It is thought that among the materials seized during the raid was a comprehensive list of past and current ISM volunteers, including their addresses and passport numbers. This enabled the Israeli security apparatus to expand its "blacklist" of unwelcome internationals, resulting in an increase of deportations and denials of entry. The ISM has never regained its earlier strength and dynamism, although the presence of international volunteers continues to this day.

Also in the spring of 2003, Israelis who had cooperated with ISM affinity groups increasingly felt the need to give more visibility to their own resistance as Israelis, and created an autonomous group working together with Palestinians and internationals. Meanwhile, construction had begun in earnest of the barrier known as the "Separation Fence" or "Apartheid Wall" in the occupied West Bank.10 After a few sporadic actions and demonstrations against the barrier, a small group started to come together and build a trusted reputation of Israeli direct-action activists willing to struggle together with Palestinian communities. In April 2003, Nazeeh Sha'labi, Hani Amer, and other farmers from the West Bank village of Mas'ha invited the group to build a protest camp on their land, from which they were about to be cut off by the fence. The protest camp became a center of information and struggle against the planned construction. Over the four-month duration of the camp, more than a thousand internationals and Israelis came to learn about the situation and join the struggle.11 During the camp, the Israeli group began naming itself Anarchists Against Fences. In English, it is normally known as Anarchists Against the Wall (AAtW; the double entendre is absent in other languages).

After the eviction of the Mas'ha camp amid ninety arrests, AAtW was invited to participate in daily actions against the construction of the wall in the village of Budrus. In the fifty-five nonviolent actions that followed in 2004, Israeli soldiers killed one protester and injured some three hundred. Pressured by the struggle and a legal precedent established in the case of Beit Surik (see below), the state finally moved the barrier west, sparing three hundred acres and three thousand olive trees.12 The year 2004 also saw the formation of popular committees against the barrier in numerous villages, who invited Israelis to participate in their struggle. Demonstrations and actions took place almost daily in Salem, Anin, Biddu, Beit Awwa, Deir Balut, Beit Surik, and Beit Likia, as well as in Palestinian neighborhoods effectively imprisoned by walls around Jerusalem. The presence of Israelis and internationals usually forced the army to avoid lethal repression, and in a few actions Palestinians and Israelis managed to halt construction work for the day, tear down or damage sections of the fence, or break through gates along it. 
From February 2005, the group mainly supported weekly demonstrations in the village of Bil'in, a resilient mobilization sustained in numbers for three years despite violent repression. A typical Friday demonstration in Bil'in (or Ni'lin) begins with a rally in the village center following Friday prayers, followed by a procession toward the fence amid chanting and drumming. To retain media interest in the protests (and to confuse and baffle the military forces), the demonstration will often have a distinguishing symbolic feature: an attempt to plant trees on the route of the fence, a staged "funeral march" declaring the death of the village due to suffocation of its livelihood, or the commemoration of a historic anniversary. An Israeli force (normally from the Border Police) awaits the protesters at the fence, or sometimes meets them en route. Though the protesters will sometimes be allowed to reach the fence, chant slogans, and be interviewed by the media, the Israeli soldiers inevitably declare the area a "closed military zone" and proceed to disperse the march using tear gas, concussion grenades, rubber-coated metal bullets, shoving, and beating.

In the fray, some demonstrators may attempt to stay at the fence or damage a section further down along it, until dispersed or arrested. As the demonstration retreats back to the village, youth from the village move to the rear-guard and begin throwing stones back at the Israeli forces, sometimes resulting in an incursion into the village by military Jeeps and more arrests. By 5 PM all is usually quiet again. Since 2005, this harrowing procedure has been repeated weekly with varying degrees of violence.

Over this period the group's composition changed almost entirely, and the physical and emotional impacts of regularized violence made themselves felt. As of 2009, there has been a regular presence of an AAtW affinity group at the Friday demonstrations in Ni'lin, Bil'in, and Ma'asra. There are ongoing relationships with a few other villages as well.

It should be noted that AAtW is only one action space within the broader Israeli anarchist movement that has mobilized for many anti-occupation demonstrations and actions in Israel. Activists have stretched barbed wire and set up a mock checkpoint in an affluent north Tel Aviv street, and briefly mounted Israeli tanks and armored personnel carriers preparing for an incursion into the Gaza Strip. There was also widespread anarchist participation in the Israeli opposition to the August 2006 war on Lebanon and the December 2008 war on Gaza. Anarchists formed large contingents in the demonstrations against these offensives, and briefly blockaded the entrance to an air force base at the height of both wars.13

\section{DYNAMICS OF MOBILIZATION}

Having surveyed the emergence and development of AAtW and its activities, I now move to discuss its mobilization dynamics through three prisms: direct action, bi-nationalism, and leadership. This section aims to highlight the significance of anarchist politics in shaping key dimensions of the mobilization, and to provide the adequate orientation for an informed assessment of its effectiveness.

\section{Direct Action}

Following one of its first actions, AAtW declared:

We forced open the gate at Mas'ha to open a gap in the wall of hatred and to provide with our actions a living, kicking alternativeto the apartheid policy of the 
Israeli government.... We work in a spirit of full cooperation, without leaders.... We believe that justice and equality are arrived at by voluntary agreement between people and that the State is only an aggressive tool of dominant ethnic / class groups.... The Berlin Wall was not dismantled by rulers and agreements, but by the citizens who felled it with their own hands.... The ethnic cleansing is occurring before our eyes and we have only one option: to use the few rights we still have from the remnants of Israeli democracy and break the racist, immoral laws.14

This is an explicitly anarchist text that connects the specific goals of the group with a broader anarchist politics. Rejecting the appeal to governments to modify their behavior, and indeed the institution of the state itself, it calls instead for direct action-physical intervention against injustice-in forms that by themselves prefigure an alternative to present systems of domination and exploitation.

Direct action is defined as action without intermediaries, whereby an individual or group uses the individual's or group's own power and resources to change reality in a desired direction, rather than appealing for the intervention of an external agent, typically a government. This is mirrored by a disinterest in operating through established legal channels or in building political power within the state. Thus, if anarchists object, for instance, to the clear-cutting of a forest, then taking direct action means that rather than lobbying legislators or petitioning the courts, they would prefer to intervene literally to hinder or halt the clearcutting-by chaining themselves to the trees, or pouring sugar into the gas-tanks of the bulldozers, or other acts of disruption and sabotage.15 Direct action has also been an important mode of action for antiwar movements since at least the advent of the antinuclear peace movements of the 1980s.16 In Britain at the beginning of the Iraq War in March 2003, anarchists blockaded munitions convoys, disrupted ground control at air bases, and caused economic damage to arms and oil companies. In the United States, the San Francisco financial district was shut down on the first day of the war by Direct Action to Stop the War (DASW), a grouping of activists and affinity groups. DASW continued to organize actions in which economic damage was caused to multinational corporations branded as war profiteers, such as Bechtel, Chevron, and Lockheed Martin.17

In the joint struggle in the West Bank, direct action is clearly present: in the nonviolent obstruction of bulldozers that successfully (if temporarily) halted the construction of the fence in various villages, in the removal of the boulders or large concrete cubes that the military uses to block Palestinian access roads, and in the collective breaking of curfews. Far from mere acts of protest, these actions, when successful, immediately and materially create the reality that the Palestinians and their Israeli and international allies seek: a halt to construction works, an open road, a normal working day.

These practices of direct action are sustained within a broader action culture that emphasizes decentralization and autonomy. Just as direct action manifests autonomy and refusal of state authority, so is the logic of centralized direction alien to anarchist organizational culture.One advantage attributed to this model is its ability to contain a diversity of tactics. While patterns and regularities do develop, the anarchist culture of direct action leaves the ground open for affinity groups to take self-organized initiative, maintaining the fluidity and dynamism required for effective intervention in a rapidly developing field of struggle.

Useful case studies for this dynamic are present in the experiences of Israeli anarchists, and are reflected in their discussions of direct action. One example is the damage done in 
November 2007 to grape vines and field-crops cultivated by Jewish settlers on the margins of a demonstration against the fence in the Bethlehem area. While these actions were spontaneous rather than planned, they raised significant discussion after the event. An activist writes to the group's e-mail list:

I feel that such actions are unacceptable. To uproot someone's livelihood, regardless of how long they've lived there or what country they're from, is out of order ethically, as well as unhelpful to meaningful social struggle (not to mention an anarchist one).18

Others, however, asserted that this was a legitimate form of direct action since it directly promoted the goal of removing the Israeli settlers from the West Bank. For example, another participant argues that

to uproot settlers' livelihood-if possible (as we try to do in our call for boycott on their products) is part of the struggle against the occupation. Any direct action against the settlers-even the nonideological ones who were lured there by economic benefit-is part of the social struggle as long as it is done socially and with good thinking.19

While space does not allow for any sustained discussion of the substantive ethical and political issues raised here, 20 this exchange indicates the highly reflexive nature of AAtW's direct-action practices. Indeed, anarchist political culture displays intensive and ongoing dialogue over the ethical dimensions of movement activity (the bulk of which takes place verbally rather than by e-mail). Even more important, the exchange highlights the value of the anarchist logic of autonomous action and decentralization for preserving movement cohesiveness despite serious differences on matters of principle. The opposite logic of homogeneity and steerage that tends to dominate centrally organized movements and parties would demand a commonly adhered-to policy in such cases, resulting either in the disciplining of minorities or in a split in the organization.

Anarchist groupings, on the other hand, are much more easily capable of sustaining cooperation and solidarity despite such differences. Structurally, the lack of any mechanism of enforcement encourages an open-ended, experimental politics in which ethical tensions can become a productive impetus for innovation in tactics on the ground. At the same time, decentralization allows individuals to cooperate with like-minded friends in an autonomous affinity group, which can inhabit the same action space with groups that do not share their precise perspective, respecting a diversity of tactics instead of expecting there to be a sense of overarching, collective responsibility for the actions of all those present. The same antiauthoritarian values on which this tactical approach is based serve as a substantive common denominator: low enough to ease frictions on all but the most extreme differences (e.g., armed struggle), and high enough to preserve a sufficiently powerful degree of solidarity and cooperation to sustain the movement as a coherent entity.

\section{Bi-Nationalism}

Direct action, addressed above in its preventative guise, can also be employed to creative and constructive ends. In this case, direct action means that anarchists, who propose social relations free of hierarchy and domination, undertake the construction of such relations by themselves in ecological communities, urban social centers, nonprofit systems of exchange and barter outside the capitalist market, and so on. In this case they are taking direct action 
to create a new society "within the shell" of the extant one.21 This is also the source of the pervasive ethos of "prefigurative politics" in contemporary anarchism, which seeks to embody the change it seeks in society through nonhierarchical organizing and mutual aid. Such a prefigurative politics not only publicly declares the viability of such alternatives - the well-known anarchist practice of "propaganda by the deed"-but also allows activists themselves a measure of self-liberation and community in their own existence-a "revolution in everyday life." 22

This constructive aspect of direct action is present in the mobilization's display of manifestly different relations between Israelis and Palestinians - ones based on partnership, solidarity, and empathy rather than estrangement, separation, and fear. The joint campaign against the Segregation Barrier has thus become a protracted experiment in bi-nationalism, a faceto-face encounter at the barricades where Israelis and Palestinians can shed their stereotyped identities toward one another and create shared communities of struggle. Says Nazeeh Sha'labi:

We wanted to show that the Israeli people are not our enemies; to provide an opportunity for Israelis to cooperate with us as good neighbors and support our struggle.... Our camp showed that peace will not be built by walls and separation, but by cooperation and communication between the two peoples living in this land. At Mas'ha Camp we lived together, ate together, and talked together twenty-four hours a day for four months. Our fear was never from each other, but only from the Israeli soldiers and settlers.23

Attention should be given to the nature of the bi-national alliance that has emerged in this campaign. The joint struggle against the fence has all along been explicitly Palestinian-led. Israeli and international activists have deliberately participated in it as followers and supporters, responding to invitations from Palestinian popular committees. Israeli anarchist Yossi Bar-Tal has argued that "we're not working in Palestine to educate.... We would never hand out leaflets in Arabic explaining what anarchism is and why you should join us, because this is not our way...we're not there to educate, because while they're being occupied by our state we have no reason to come there and preach." 24 Here, the importance of an anarchist perspective again comes to the fore in clearly differentiating the practice of joint struggle from the existing host of well-funded and thoroughly depoliticized dialogue and coexistence projects. The latter is a burgeoning industry, ranging from the Seeds for Peace summer camps and youth dialogue programs to shared Israeli- Palestinian exhibitions and roundtables in European and North American cities. The deep problem with such projects, for Palestinian and Israeli dissidents alike, is that their premises and language mask the realities of the occupation under the false pretense of equality between the participants. Casting the root causes of the conflict in terms of mutual ignorance and suspicion "on both sides," they tend to paper over the grossly unequal power relations at play, and thus amount to an unacceptable attempt to normalize relations between Palestinians and Israelis as if the occupation were already over. 25

In contrast, the practice of joint struggle takes place in full recognition of the inequalities between the Israeli and Palestinian participants - in terms of economic resources, freedom of movement, safety from arbitrary state violence, and so on. This recognition is partly made possible by the Israeli participants' anarchist perspective, which so distances them from the Zionist narrative as to render unnecessary the artificial neutrality maintained by the discourse of coexistence. Rather, the joint struggle remains infused with a spirit of shared antagonism toward the regime of occupation, and a refusal of false normalization. 
Leadership

Issues of leadership and intragroup power dynamics have been contentious within radical social movements since at least the late 1960s. The matter is particularly sensitive in anarchist groups and networks, whose commitment to a prefigurative politics drives them to aspire to egalitarian group relations and, if not the lack of any leadership, at least the even distribution or fluid rotation of leading roles and positions among the participants. Yet as the case of AAtW demonstrates, the aspiration to "work in a spirit of full cooperation, without leaders" is often frustrated by the congealing of informal concentrations of power. In June 2006, a participant in the group wrote to its e-mail list:

I am deeply frustrated to see that in the Israeli anarchist movement there are leaders - those strong and charismatic men who boast many arrests and media exposure, who everyone follows and listens to. So they say that they're anarchists and have no rank insignia on their shoulders, and a large part of the decisions taken with their help are taken by majority in "democratic" decisions, but in practice everything is directed according to their wishes under the surface, and in practice their voice is larger, more thundering and more equal than others. 26

While discussions of unaccountable power in the movements of the late 1960s highlighted the dynamics of in-groups and social cliques, 27 the message may express a deeper feminist critique, what several women in AAtW have characterized in interviews as its masculine culture of activity and leadership. While there has remained a rough numerical equality between men and women in leadership roles, it is not at all clear that this reflects a feminist process or a genuine challenging of gender roles. In conversations with the author, a number of women in the group have pointed to a culture that requires them to emulate the selfconfident, space-taking behaviors of the men. The group's short-term focus on organizing demonstrations also drew their criticism as a masculine "'wham, bam, thank you ma'am politics" -in opposition to the less spectacular but more sustained politics of building projects of mutual aid with the villages.

Attention should also be drawn to important structural sources of leadership dynamics. In particular, research has highlighted the unequal distribution of political resources as key to the generation of power to act in informal movements.28 Such inequalities "will not generate domination, if by that we mean actors' capacity to impose sanctions over others in order to control their behavior, but rather varying degrees of influence. The latter may consist, for example, of actors' ability to promote coalition work among movement organizations." 29 Thus, political resources prone to unequal distribution include not only access to funds or to material infrastructures such as meeting spaces and vehicles but also immaterial resources (cultural capital): skills, knowledge, and personal contacts.

The particular importance of contacts and networking capability as a political resource for activists is stressed by Jeff Juris in his ethnography of radical networks in Barcelona. Juris discusses the role of individuals who form powerful nodes in social movement networks by acting as network "relayers" and "switchers" who

decipher, combine and recombine cultural codes, thereby allowing for the circulation of information among diverse network formations.... Despite the prevailing discourse of egalitarianism, they occupy key positions of power, allowing 
them to significantly influence the flow, direction and intensity of network activity.30

In the case of AAtW, this particular political resource seems to be most central to the generation of unequal influence in the group. This is because of the pivotal place of the direct personal contact with the leaders of the popular committees in various Palestinian villages against the fence. Only a small number of participants in the group have the time and resources to travel around the West Bank and establish these connections. Moreover, newly established popular committees who seek the group's support for their demonstrations will normally turn to existing Palestinian committees to supply them with the relevant contacts, and these will naturally refer them to the activists they already work with. Redistribution of this political resource in a way that will generate more equality in the group is very difficult. Based on an accumulation of personal familiarity and trust, the relationship with a given Palestinian coordinator is not immediately transferable to another activist who is a stranger to him.

\section{SUSTAINABILITY AND EFFECTIVENESS}

The anarchist dimensions of the AAtW initiative discussed so far will prove important in establishing the goals against which to assess its degree of success and effectiveness. Before doing so, however, I would like to briefly discuss a major factor influencing the effectiveness of AAtW and direct-action groups more generally, the capability to manage burnout as a result of exposure to state repression.

While attracting media attention, repression is both physically and emotionally dangerous to participants and weakens groups' long-term sustainability.31 As described above, exposure in Bil'in to teargas, truncheon blows, and concussion grenades has become a matter of weekly regularity. While obviously not equal to the lethal brutality directed toward Palestinians, the frequency of Israeli anarchists' experiences of violent state repression is certainly considerable compared to their European and North American counterparts.

On December 26, 2003, at a demonstration in Mas'ha, a young Israeli named Gil Na'amati became the first Israeli to be seriously injured by soldiers in the struggle against the barrier, sustaining major blood loss from a live bullet to the thigh and nearly losing his life. There have also been a number of cases in which Israelis were shot in the head with teargas canisters and rubber-coated metal bullets, one of them sustaining a serious injury. The Israeli forces have also been using demonstrations in the West Bank as an opportunity to test novel "less lethal" weapons such as pepperballs (a small transparent red plastic ball containing an extremely irritant powder) and the Tze'aka (Hebrew for "scream"), a minutelong blast of deafening sound emanating from a vehicle-mounted device that causes nausea and imbalance. 32

Paradoxically, the joint struggle's profile in the Israeli media rose mostly following injuries to Israeli participants (at least ten Palestinians have been killed in the campaign). Up to Na'amati's injury, AAtW had operated largely below the Israeli public's radar screen, despite all its efforts to attract media attention. But the state's use of potentially lethal violence against Jewish citizens made the resistance dramatically visible, generating fierce public debate about the army's suppression of unarmed protesters. Though the media frenzy largely revolved around army tactics, a conversational space was also created within the mainstream Israeli media for critiques of the policy of separation. 33 
The high media profile generated by state repression has come at the price of widespread posttraumatic stress among AAtW participants, resulting in burnout and retreat from activity. Posttraumatic stress is an issue that is only beginning to be addressed in directaction movements worldwide. 34 In the wake of repression, activists commonly experience anxiety, depression, panic attacks, and hypervigilance, as well as any number of physical symptoms from chronic fatigue and muscular tension to irregular pulse and menstrual changes. With the AAtW initiative, the accumulation of untreated posttraumatic stress has been a hindrance to the initiative's vitality and sustainability. Close familiarity with the group indicates that one reason for the neglect to treat the long-term effects of repression has been an ethos of personal sacrifice and resilience that animates more than one of the participants. Most recently, however, the group has begun giving more deliberate attention to these issues, and a team of Israeli activists who trained in posttrauma support is offering counseling sessions, workshops, and publications on the issue.

In coming to assess the overall effectiveness of AAtW and the joint struggle against the fence, it is necessary to define carefully the goals against which such assessment is to be made. While the immediate success or failure of direct action on the ground is clearly an important criterion, the fact that participants have couched this activity in terms of a broader anarchist politics, and the group's rootedness in an antiestablishment subculture, point to a more complex array of goals to be considered. 35 I would therefore like to suggest a three-level assessment based on short-, medium-, and long-term goals.36 Shortterm goals include the successful disruption or halt to construction works on particular sections of the fence, as they come to be resisted by Palestinian villagers. In the medium term, the campaign clearly expresses a more basic antimilitarist and bi-nationalist agenda: opposition to the Israeli government's rationale of separation, and to its declaration that "there is no partner" on the Palestinian side. Finally, goals of a long-term order are introduced by the group's opposition, not only to the occupation as such, but more radically to dominant social institutions such as capitalism and the state, which anarchists ultimately seek to overthrow.

If this is the case, then the results are clear. Short-term goals were almost never reached. Despite delays and an increase in the costs of construction, the first three stages of the fence are now all but complete. In the few cases where the course of the fence was changed and land confiscations canceled, the evident cause was not direct action on the ground but rather the successes of the villagers' petitions to the Israeli Supreme Court. Following two injunctions that determined that the planned routes of the fence near Beit Surik and Azzoun were disproportionately harmful to Palestinians' everyday lives, 37 the Israeli army preemptively altered the planned route of the fence in other areas, including the village of Budrus, whose appeal was resultantly dismissed. 38 In the case of Bil'in, it was again the Supreme Court that instructed the state to propose an alternative route for the fence that would return much of the village's confiscated agricultural land. This was after the petitioners proved that the route was plotted in reference to a planned extension of the settlement of Upper Modi'in, the land for which was illegally appropriated. 39 At the same time, it is clear that the support of AAtW and international activists did embolden the villagers, and played a part in sustaining their determination to go through the legal channels in addition to their protests. It can also be argued, though not proved, that the high profile of the struggle against the fence in the petitioning villages contributed to swaying the considerations of the Supreme Court judges, who have rejected petitions against the route of the fence in the vast majority of cases. The long-term goals were obviously not achieved: the occupation continues, and no social revolution against capitalism and the state can be seen on the horizon. Indeed, there appear to be inherent limitations to the enactment of a full revolutionary anarchist politics in situations of proximate military conflict. The intensity 
of everyday violence and the concentration of public discussion on security issues tend to foreclose the discussion of broader social agendas, and certainly all talk of a radically new society. Thus, the dynamism and energy of the small Israeli anarchist movement has largely been consumed by the grind of organizing regular solidarity protests and direct actions.

Despite this, it would be an error to write off the AAtW campaign as ineffectual. This is because the medium-term goals - building a joint struggle, delegitimizing the policy of separation, and exposing the lie of the "no partner" formula-were reached almost immediately. The presence of Israelis and internationals did force the army to significantly reduce its levels of repression against the protesting Palestinians, and enabled sustained campaigns of protest and direct action against the fence. The practice of direct, face-to-face cooperation with Palestinans has been transformed from a rare exception to the paradigm of antioccupation activity in the broader Israeli Left, and has proven that there are indeed partners on the Palestinian side who are prepared to build relations of mutual aid and respect with Israelis. The joint struggle may also have succeeded in delegitimizing the barrier. Between October 2003 and April 2006, the minority of Israelis objecting in principle to the construction of the barrier almost doubled, from $6.8 \%$ to $12.8 \% .40$ While hard causal links between movement activities and pubic opinion are impossible to establish, it appears at least plausible that the joint struggle contributed to this, not only by rendering visible the humanitarian plight caused by the fence but also (and more incisively) by highlighting its political role as a measure of de facto land annexation that eats away at the territorial continuity and viability of any future Palestinian state.

The joint struggle can be said to have generated a meaningful interference with the hegemonic construction of reality in Israeli discourse. Most important, it has powerfully challenged the construction of the Palestinian "other" as a faceless, intractable enemy determined to drive Jews into exile or worse. That this was an explicit goal of AAtW is clearly indicated by another part of its statement quoted above:

Since we can remember, we have been brainwashed with hatred and fear of our Palestinian neighbours.... We were told that our hand is extended for peace but there is no-one to talk to. But these lies were exposed and are clear for every one who participates in the actions against the occupation to see. We have slept together beneath the olive trees (before they were uprooted), we have marched together to the fence and we will continue to struggle together-Israelis, Palestinians and internationals - for justice and equality for all.41

It is important to emphasize how transgressive the practice of joint struggle is in the context of the hegemonic Israeli public consciousness. The sight of Israelis demonstrating shoulder to shoulder with Palestinians fundamentally transgresses the taboos put in place by Zionist militarism, forcing Jewish spectators to confront their own dark collective traumas. To put things bluntly, through their actions, the Israeli protesters are effectively declaring that they refuse to buy into the discourse that draws a direct line between Palestinian liberation and a Second Holocaust. The abrasive work done by this symbolic interference is evinced by the vitriolic "talk-backs" invariably following reports on AAtW actions in mainstream media Web sites, in which they are regularly attacked as traitors and enemies from within who are fostering the end of the Jewish people. The anarchist culture of creative provocation functions as a tool for exposing the unspoken, and contributes to challenging mainstream Israeli victims' guilt, continually expatiated through the assertion of self-defense and just war as unexamined axioms. 
In summary, despite its failure to achieve directly its immediate goals, the AAtW campaign has succeeded in mounting a significant ideological challenge to the Israeli government's policy of separation and land confiscation. The joint struggle thus remains one of the few sources of inspiration and hope in the harsh reality of the Israeli- Palestinian conflict.

\section{NOTES}

1. Beltra'n Roca Martı́nez, "Anarchism, Anthropology and Andalucia: An Analysis of the CNT and the 'New Capitalism'," in Anarchist Studies Vol. 14, No. 2 (2006): 106-130; David Graeber, Direct Action: An Ethnography (Oakland, California: AK Press, 2009); Jeffrey S. Juris, Networking Futures: The Movements Against Corporate Globalization (Durham, North Carolina: Duke University Press, 2008); Uri Gordon, Anarchy Alive! Anti-Authoritarian Politics from Practice to Theory (London: Pluto, 2008).

2. Richard Day, Gramsci Is Dead: Anarchist Currents in the Newest Social Movements (London: Pluto, 2005); Barbara Epstein, "Anarchism in the Anti-Globalization Movement," in Monthly Review Vol. 53, No. 4 (2001). http://www.monthlyreview.org/0901epstein.htm; David Graeber, "The New Anarchists," in New Left Review 13 (2002).

http://newleftreview.org/A2368; Andrej Grubacic, "Towards Another Anarchism," in World Social Forum: Against all Empires, ed. Jai Sen et al. (New Delhi: Viveka, 2004).

3. Uri Gordon, "Anarchism Reloaded," in Journal of Political Ideologies Vol. 12, No. 1 (2007): 29-48; Michael Freeden, Ideologies and Political Theory: A Conceptual Approach (Oxford: Clarendon, 1996).

4. James Horrox, A Living Revolution: Anarchism in the Kibbutz Movement (Oakland, California: AK Press, 2009); Moshe Goncharok, "The Yiddish Anarchist Press," in Bollettino de l'Archivio G. Pinelli 15, trans. Jesse Cohn (2005).

http://raforum.info/article.php3?id article=2368.

5. Derek Wall, Earth First! and the British Anti-roads Movement (London: Routledge, 1999). 6. Anonymous, "Direct Action in Israel: Impressions from a Roving EF!er," in Do or Die 8 (1999): 221-224. http://www.eco-action.org/dod/no8/israel.html.

7. One Struggle, About Us (2002). http://www.onestruggle.org/english_frameset2.htm. Accessed January 4, 2010.

8. Charles Horwitz, an interview with Ghassan Andoni, Ethically Speaking Vol. 98, No. 7 (2004). http://www.bsec.org/reference/bsec/newsletter/files/bsec0304.pdf.

9. Josie Sandercock et al., eds., Peace Under Fire: Israel / Palestine and the International Solidarity Movement (London: Verso, 2004).

10. B'tselem, Separation Barrier (2007).

http://www.btselem.org/english/Separation_Barrier/Index.asp. Accessed January 4, 2010.

11. Uri Ayalon, "Resisting the Apartheid Wall," in We Are All Anarchists Against the Wall, in Federazione dei Comunisti Anarchici. Fano: I Quaderni di Alternativa Libertaria (2004): 3-13. http://www.fdca.it/wall/media/anarwall_EN.pdf; Aaron Lakoff, "Israeli Anarchism: Being Young, Queer and Radical in the Promised Land," in Anarchist Studies Vol. 13, No. 2 (2005). http://aaron.resist.ca/node/33.

12. Ida Audeh, "A Village Mobilized: Lessons from Budrus," The Electronic Intifada, June 13, 2007. http://electronicintifada.net/v2/article7005.shtml.

13. For regular updated footage, see http://www.youtube.com/user/davidreeb.

14. Anarchists Against the Wall, AAtW Declaration, in We are All Anarchists Against the Wall, 49-50.

15. Benjamin Seel, Matthew Paterson, and Brian Doherty, eds., Direct Action in British Environmentalism (London: Routledge, 2000); Brian Doherty, Alexandra Plows, and Derek Wall, "'The Preferred Way of Doing Things': The British Direct Action Movement," in Parliamentary Affairs 56 (2003): 669-686. 
16. Anne Seller, "Greenham: A Concrete Reality," in Frontiers: A Journal of Women Studies Vol. 8, No. 2 (1985): 26-31; Joyce Marie Mushaben, "Grassroots and Gewaltfreie Aktionen: A Study of Mass Mobilization Strategies in the West German Peace Movement," in Journal of Peace Research Vol. 23, No. 3 (1986): 141-154.

17. Scott Campbell, "Five Years Later, Direct Action to Stop the War Reemerges," CounterPunch, February 1, 2008. http://www.counterpunch.org/campbell02012008.html; Dana Williams, "Feeder Marches and 'Diversity of Tactics' in Northeast Ohio Anti-war Activism," Research on Anarchism Forum, January 1, 2007. http://raforum.info/article.php3?id_article=2194.

18. Eran, RE: Olive uprooting etc., message to the email list [againstwall], November 20, 2007.

19. Nali, RE: Olive uprooting etc., message to the email list [againstwall], November 20, 2007.

20. cf. Gordon, Anarchy Alive!, 78-108.

21. cf. Gustav Landauer, "Schwache Stattsma"nner, Schwacheres Volk!," Der Sozialist, June 10, 1910, in Prophet of Community: The Romantic Socialism of Gustav Landauer, trans. Eugene Lunn (Berkeley: University of California Press, 1973), 226.

22. cf. John Holloway, "Is the Zapatista Struggle an Anti-Capitalist Struggle?," in The Commoner 6 (2003). http://www.commoner.org.uk/holloway06.doc; John Carter and Dave Morland, "Anti-Capitalism: Are We All Anarchists Now?," in Anti-capitalist Britain, ed. John Carter and Dave Morland (Gretton, United Kingdom: New Clarion Press, 2004).

23. Nazeeh Sha'alabi, The Camp in the Eyes of a Palestinian Activist (2003). http://stopthewall.org.il/mashacamp/TheCampInTheEyesOfPalestinianActivist. html. 24. Interviewed in Lakoff, "Israeli Anarchism."

25. Ban Saifer, "Shalom-Salaam? Campus Israel Advocacy and the Politics of 'Dialogue'," in Upping the Anti 9 (2009); Yael Berda, "Peace on You, the Professional Left," in Mitsad Sheni 14 (2006): 14-18; Mohammed Abu-Nimer, "Education for Coexistence and Arab-Jewish Encounters in Israel: Potential and Challenges," in Journal of Social Issues Vol. 60, No. 2 (2004): 405-422.

26. Oshgili, Anarchism and Leaders, message to the list [againstwall], June 10, 2006. Author translation.

27. Jo Freeman, "The Tyranny of Structurelessness" (1970); Cathy Levine, "The Tyranny of Tyranny" (1972), in Quiet Rumors: An Anarcha-Feminist Anthology, ed. Dark Star Collective (London: Rebel Press, 2002).

28. Jonathan Purkis, "Leaderless Cultures: The Problem of Authority in a Radical Environmental Group," in Leadership and Social Movements, ed. Colin Barker, Alan Johnson, and Michael Lavalette (Manchester, United Kingdom: Manchester University Press, 2001); cf. Pierre Bourdieu, Outline of a Theory of Practice (Cambridge: Cambridge University Press, 1977); Gordon, Anarchy Alive!, 55-61.

29. Mario Diani, “'Leaders' or Brokers? Positions and Influence in Social Movement Networks," in Social Movements and Networks: Relational Approaches to Collective Action, ed. Mario Diani and Doug McAdam (Oxford: Oxford University Press, 2003), 106.

30. Jeff Juris, Digital Age Activism: Anti-Corporate Globalization and the Cultural Politics of Transnational Networking. PhD thesis, University of California at Berkeley, 2004, p. 49. 31. James Downton Jr. and Paul Wehr, "Persistent Pacifism: How Activist Commitment Is Developed and Sustained," in Journal of Peace Research Vol. 35, No. 5 (1998): 543.

32. Steven Rose, "Israel's Other Weaponry," Palestine News, Summer 2006.

33. Meron Benvenisti, "A Little Anarchism Won't Hurt," Haaretz, January 1, 2004.

34. See, e.g., http://www.activist-trauma.net.

35. Kim Salomon, "The Peace Movement-An Anti-Establishment Movement," in Journal of Peace Research Vol. 23, No. 2 (1986): 116-127. 
36. Here I follow David Graeber, "The Shock of Victory," Infoshop News, October 12, 2007. http://news.infoshop.org/article.php?story=2007graeber-victory.

37. State of Israel, High Court of Justice, Verdict in HCJ 2056 / 04, Beit Surik Village Council VS The Government of Israel, June, 30, 2004.

http://elyon1.court.gov.il/Files/04/560/020/a28/04020560.a28.pdf; Verdict in HCJ 7957/04, Zahran Mra'abe VS The Prime Minister, September, 15, 2005.

http://elyon1.court.gov.il/Files/04/570/079/a14/04079570.a14.pdf.

38. State of Israel, High Court of Justice, Verdict in HCJ 4825 / 04, Muhammad Aliyan VS The Prime Minister, March, 16, 2006.

http://elyon1.court.gov.il/Files/04/250/048/a36/04048250.a36.pdf.

39. State of Israel, High Court of Justice, Verdict in HCJ 8414 / 05, Ahmad Yassin VS The Government of Israel, September 4, 2007.

http://elyon1.court.gov.il/Files/05/140/084/n25/05084140.n25.HTM.

40. Ephraim Ya'ar et al., The Peace Index (monthly poll of the Tami Steinmetz Center for Peace Research, Tel-Aviv University, 1994-2008). http://www.tau.ac.il/peace.

41. AAtW declaration in We Are All Anarchists Against the Wall. 